\title{
LATERAL DENSITY DIFFERENCES FROM SEISMIC MEASUREMENTS AT A SITE ON THE ROSS IGE SHELF, ANTARCTICA*
}

\author{
By Joseph F. Kirchner $\dagger$, Gharles R. Bentley, \\ Geophysical and Polar Research Center, Department of Geology and Geophysics, University \\ of Wisconsin-Madison, Madison, Wisconsin 53706, U.S.A.) \\ and JAMEs D. RoBertson \\ (Atlantic Richfield Company, P.O. Box 2819, Dallas, Texas $75^{22}$ I, U.S.A.)
}

\begin{abstract}
Seismic compressional-wave data from short refraction shooting carried out during the I $974-75$ and $1976-77$ seasons at J-9, the site of the Ross Ice Shelf Drilling Project, have been compared. Significant dissimilarities were found to exist between the two sets of data. The measurements were made at locations about $2 \mathrm{~km}$ apart, with three unreversed profiles $60^{\circ}$ apart recorded during the $1976-77$ season and one unreversed profile during the $1974-75$ season. The resulting velocity-depth profiles, and hence the derived density-depth profiles, differ by as much as $8 \%$, with the $1976-77$ results indicating a maximum velocity, corresponding to solid ice, at a shallower depth than the $1974-75$ data. Both profiles were subjected to the same analysis, and a comparison of travel-time curves shows the differences to be real. Densities measured on cores from a $100 \mathrm{~m}$ bore hole drilled in $1974-75$ about $50 \mathrm{~m}$ from the center of the $1974-75$ profile agree well with densities computed from that profile. The density difference is believed to be due to the passage of the ice through the high-stress system associated with the interaction between Ice Stream B, flowing in from the West Antarctic ice sheet, and the Ross Ice Shelf. A reversed refraction profile carried out at station B.C. about $30 \mathrm{~km}$ up-stream, shows evidence of dipping layers that may be similarly caused.

RÉsumé. Variations de densité sur un site du Ross Ice Shelf, Antarctique à partir de sondages sismiques. Des données sur les ondes sismiques de compression ont été recueillies à partir de tirs à courte réfraction pendant les saisons $1974-75$ et $1976-77$ à J-9 le site du Ross Ice Shelf Drilling Project et ont été comparées. On a trouvé des différences significatives entre les deux séries de résultats. Les mesures ont été faites en des points éloignés de $2 \mathrm{~km}$ avec trois profils aller séparés à $60^{\circ}$ pendant la saison 1976-77 et un profil aller et retour pendant la saison I 974-75. Les profils vitesse-profondeur et les profils densités-profondeur qui en résultent diffèrent de $8 \%$. Les résultats de $1976-77$ indiquent une vitesse supérieure, correspondant à de la glace compacte à une moindre profondeur que ceux de $1974-75$. Les deux profils ont été soumis aux mêmes traitements et la comparaison des courbes trajet-temps montrent que les différences sont réelles. Les densités mesurées sur des échantillons provenant d'un forage de $100 \mathrm{~m}$ réalisé en $1974-75$ à environ $50 \mathrm{~m}$ du centre du profil $1974-75$ est en bon accord avec les densités calculées à partir de ce profil. On pense que la différence est une trace restant du passage de la glace dans un secteur à fortes contraintes associées à l'interaction entre le courant de glace B s'écoulant de la calotte glaciaire Ouest Antarctique et le Ross Ice Shelf. Un profil par réfraction aller et retour mesuré à la station B.C. environ $30 \mathrm{~km}$ en amont montre l'existence de niveaux plongeants qui peuvent avoir la même origine.
\end{abstract}

Zusammenfassung. Seitliche Dichteunterschiede an einer Stelle des Ross Ice Shelf, Antarktika, bestimmt aus seismischen Messungen. Werte von Kompressionswellen, gewonnen aus seismischen Refraktionsmessungen auf kurze Distanz während der Kampagne 1974-75 und 1976-77 auf der Station J-9, dem Ort der Ross Ice Shelf Drilling Project, wurden verglichen. Zwischen den beiden Datensätzen wurden signifikante Abweichungen festgestellt. Die Messungen waren an Stellen mit ca. $2 \mathrm{~km}$ Abstand mit drei Profilen unter je $60^{\circ}$ während der Kampagne 1976-77 und mit einem Profil während der Kampagne 1974-75, jeweils ohne Gegenschuss, durchgeführt worden. Die sich ergebenden Geschwindigkeit-Tiefen-Profile und damit die daraus abgeleiteten Dichte-Tiefen-Profile, differieren bis zu 8\%, wobei die Ergebnisse von 1976-77 eine maximale Geschwindigkeit, entsprechend der von festem Eis, in einer geringeren Tiefe als die von 1974-75 aufweisen. Beide Profile wurden derselben Analyse unterzogen; ein Vergleich der Laufzeitkurven erweist die Unterschiede als reell. Dichten, die an Kernen aus dem 1974-75 abgeteuften, roo m tiefen Bohrloch etwa $50 \mathrm{~m}$ neben dem Mittelpunkt des Profiles von 1974-75 gemessen wurden, stimmen gut mit den aus diesem Profil berechneten Dichten überein. Der Dichteunterschied wird für eine Auswirkung der Passage des Eises durch das System hoher Spannung gehalten, das aus der Wechselwirkung zwischen dem Eisstrom B, der vom westantarktischen Eisschild zufliesst, und dem Ross Ice Shelf entsteht. Ein Refraktions profil mit Gegenschuss von der $30 \mathrm{~km}$ stromaufwärts gelegenen Station B.C. beweist das Vorhandensein geneigter Schichten, die ähnlich entstanden
sein dürften.

* University of Wisconsin. Geophysical and Polar Research Center, Contribution No. 356.

$\uparrow$ Now at: Atlantic Richfield Company, rgoo St James Avenue, Houston, Texas 77056, U.S.A. 


\section{INTRODUGTION}

One of the objectives of the Ross Ice Shelf Geophysical and Glaciological Survey (RIGGS) was to determine density profiles from the surface down to the firn-ice boundary (upper $70-100 \mathrm{~m}$ ) by seismic measurements of the variation of the compressional-wave (P-wave) velocity with depth and then by relating $\mathrm{P}$-wave velocity to density using an empirical formula presented by Kohnen (1972). In this paper we present the results of seismic refraction experiments performed at station $\mathrm{J}-9$, the site of the Ross Ice Shelf drilling project. The results are interesting because they indicate the existence of a large lateral density change between two sites only $2 \mathrm{~km}$ apart in a region far removed from any apparent large stress gradients.

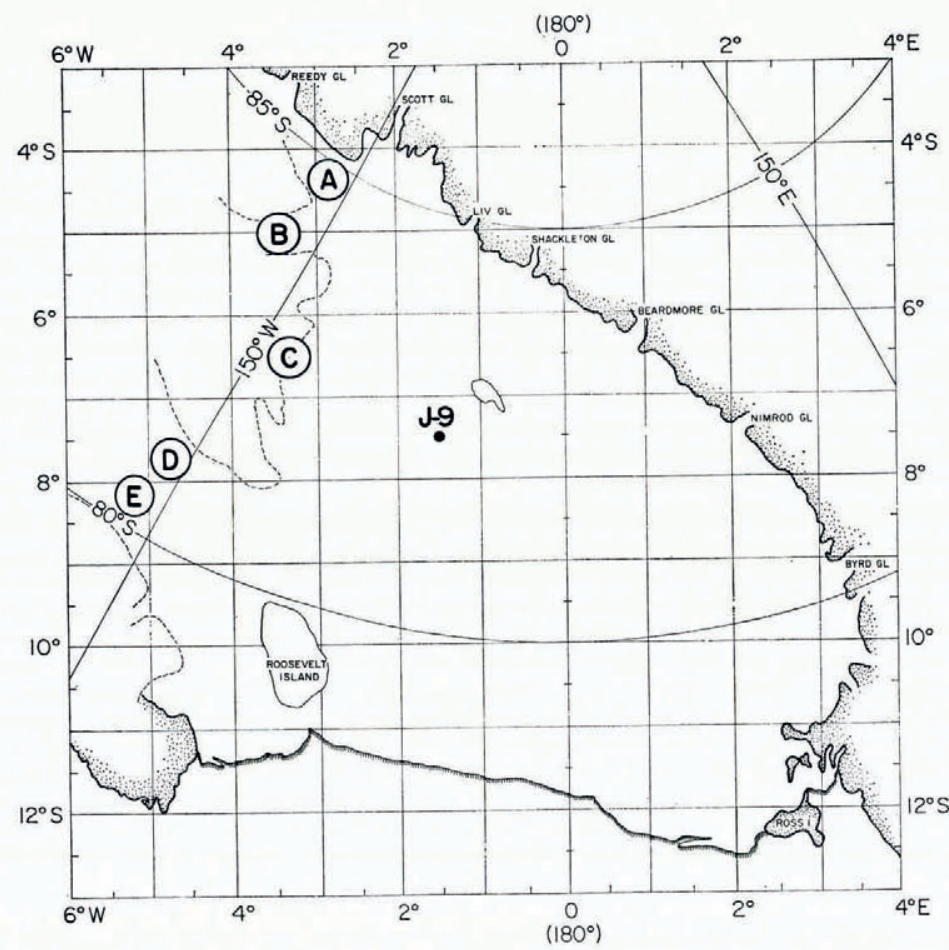

Fig. I. Map of the Ross Ice Shelf showing the location of station 7-9 where the measurements of this paper were made. Circled letters denote ice streams.

Station J-9 is located at $82^{\circ} 22^{\prime} 30^{\prime \prime}$ S., and $168^{\circ} 37^{\prime} 33^{\prime \prime}$ W. (Fig. I). One of the refraction experiments (Profile I) was conducted during the 1974-75 Antarctic field season, the other (Profile 2) in the 1976-77 season. Both profiles were oriented north-south (magnetic). The receiver spacing varied from 2 to $10 \mathrm{~m}$, depending on the shot-point distance. The energy source was either a hammer blow on a wooden stake or the detonation of an explosive charge. The 1974-75 measurements were made with a Texas Instruments $7000 \mathrm{~B}$ 24-channel seismograph, those in 1976-77 were made with an SIE 24-channel seismograph. Differences due to instrumental effects were found to be negligible.

The $1976-77$ refraction experiments included a seismic recording along two other lines at angles of $60^{\circ}$ on either side of Profile 2, for the purpose of investigating the dependence of velocity on direction. A comparison of the time-distance curves for the three lines showed only negligible differences, indicating that the constant-velocity horizons beneath Profile 2 are essentially horizontal. 


\section{DAta ANALYSIS}

Travel times were read from the seismograms with an estimated error of $0.3 \mathrm{~ms}$ using a magnification of seven times. Time-distance curves for Profiles I and 2 are displayed in Figure 2; a clear divergence of as much as $3 \mathrm{~ms}$ is evident.

Both data sets were analyzed by fitting a non-linear expression to the time-distance curves (Kirchner, unpublished),

$$
t=a_{\mathrm{I}}\left\{\mathrm{I}-\exp \left(-a_{2} x\right)\right\}+a_{3}\left\{\mathrm{I}-\exp \left(-a_{4} x\right)\right\}+a_{5} x,
$$

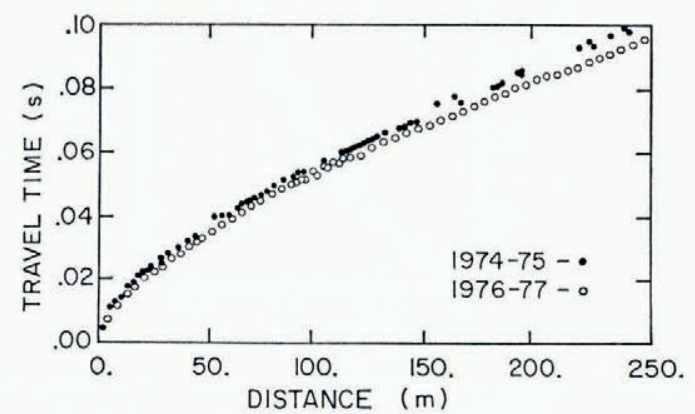

Fig. 2. Compressional-wave travel-time curves for the two profiles at 7-9. Solid circles denote the 1974-75 measurements; open circles indicate the measurements made about $2 \mathrm{~km}$ away in $1976-77$.

where $x$ is the shot-detector distance, $t$ is the predicted travel time, and the $a_{i}$ are the constants to be determined by the best fit. This method has the advantage of being free from observer bias and it ensures complete reproducibility. Also, the slopes can easily be obtained by differentiating Equation (I). Equation (I) is evaluated using non-linear regression analysis (see Kirchner, unpublished, for a more detailed discussion).

After obtaining the velocities as a function of distance, velocities as a function of depth were calculated using the standard Wiechert-Herglotz-Bateman integral. Densities were then derived using Kohnen's empirical equation (Kohnen, I972),

$$
\rho(z)=0.915\left[\mathrm{I}+\left\{\frac{v_{\mathrm{P}_{1}}-v_{\mathrm{P}}(z)}{2.25}\right\}^{\mathrm{I} .22}\right]^{-\mathrm{I}},
$$

where $\rho(z)$ is the density (in $\mathrm{Mg} \mathrm{m}^{-3}$ ) at the depth $z$ at which the P-wave velocity equals $v_{\mathrm{P}}(z)$ (in $\left.\mathrm{m} \mathrm{s}^{-1}\right)$, and $v_{\mathrm{P}_{\mathrm{i}}}=3860 \mathrm{~m} \mathrm{~s}^{-1}$, the $\mathrm{P}$-wave velocity in ice. The errors in the densities are estimated to be $\pm 0.018 \mathrm{Mg} \mathrm{m}^{-3}$ at the surface, decreasing to $\pm 0.006 \mathrm{Mg} \mathrm{m}^{-3}$ at $40 \mathrm{~m}$ depth and to about $\pm 0.002 \mathrm{Mg} \mathrm{m}^{-3}$ at the final depth. (This analysis does not take into account the effect of temperature, the correction for which would increase the density by a maximum of $0.002 \mathrm{Mg} \mathrm{m}^{-3}$.)

Robertson (unpublished), who originally analyzed Profile I, found good agreement between densities derived seismically and those measured on cores from the Ioo-m hole nearby (personal communication from C. C. Langway, Jr, I975) (Fig. 3). On the other hand, densities derived from Profile 2, also shown in Figure 3 , are significantly greater. The indication is that there is a significant horizontal variation in density between the two sites. Two possible causes can be suggested for this: The first is that some physical change occurred in the J-9 area during the two-year time period. However, this seems highly unlikely since the differences are marked at depths greater than $20 \mathrm{~m}$ but negligible near the surface.

A more plausible possibility is that the effect is associated with the interaction between ice stream B and the ice shelf. The occurrence of large stresses is indicated by the heavilycrevassed boundary area that terminates about $100 \mathrm{~km}$ up-stream from station $\mathrm{J}-9$ (fig. Io in 


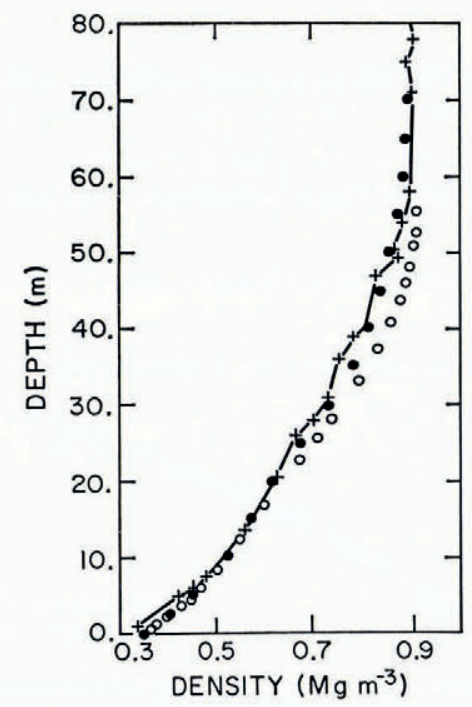

Fig. 3. Density-depth curves. Densities measured on cores are shown by crosses; those determined from the seismic velocities are shown by solid circles for the 1974-75 profile and by open circles for the 1976-77 profile.

Jezek and others, 1979). For an ice-shelf velocity of about $350 \mathrm{~m} \mathrm{a}^{-1}$ (Thomas, 1976[a]), that distance corresponds to an estimated age of about 300 years. The disturbed surface from the crevassed zone would thus be buried at J-9 at a depth corresponding to 300 years of undisturbed snow accumulation, i.e. about $30 \mathrm{~m}$ (Thomas, 1976[b]). This agrees roughly with the depth to the top of the density anomaly. In support of the idea of up-stream deformation is the earlier discovery by Robertson (unpublished) of significantly different values for the maximum $\mathrm{P}$-wave velocity along reversed profiles, indicating a dipping structure (not necessarily dipping smoothly), at RIGGS $1973-74$ base camp (station B.C.) about $30 \mathrm{~km}$ up-stream.

No more detailed interpretation can be made without making further velocity-depth maps. It is worth emphasizing, however, that the assumption of lateral homogeneity of density in low-stress regions may be invalid in regions down-stream of high-stress zones.

\section{Acknowledgements}

The authors are grateful particularly to Henry Pollak for field assistance during the 1976-77 season. This research was supported by National Science Foundation grants $\mathrm{OPP}_{72-05802}$ and $\mathrm{DPP}_{76-01415}$.

\section{REFERENCES}

Jezek, K. C., and others. 1979. Electromagnetic sounding of bottom crevasses on the Ross Ice Shelf, Antarctica, by K. C. Jezek, C. R. Bentley, and J. W. Clough. Journal of Glaciology, Vol. 24, No. 90, p. 32 I-30.

Kirchner, J. F. Unpublished. Seismic refraction studies on the Ross Ice Shelf, Antarctica. [M.S. thesis, University of Wisconsin-Madison, 1978.]

Kohnen, H. 1972. Über die Beziehung zwischen seismischen Geschwindigkeiten und der Dichte in Firn und Eis. Zeitschrift für Geophysik, Bd. 38, Ht. 5, p. 925-35.

Robertson, J. D. Unpublished. Geophysical studies on the Ross Ice Shelf, Antarctica. [Ph.D. thesis, University of Wisconsin-Madison, 1975.]

Thomas, R. H. 1976[a]. Ice velocities on the Ross Ice Shelf. Antarctic Fournal of the United States, Vol. I I, No. 4, p. $279-8 \mathrm{I}$.

Thomas, R. H. 1976[b]. Thickening of the Ross Ice Shelf and equilibrium state of the West Antarctic ice sheet. Niature, Vol. 259, No. 5540, p. 180-83. 